\title{
Influence of the Upper Limb Motor Deficit on Functional Independence in Patients with Cerebral Palsy
}

\author{
Corina SPOREA ${ }^{1,2}$, Dumitru FERECHIDE
}

\begin{abstract}
Cerebral palsies (CPs) disturb the voluntary movement control at extremities' level, entailing various disability degrees. In over $80 \%$ of the CP cases there is an upper limb disorder, mainly manifested by the decrease in hand control and the presence of contractures ${ }^{1}$, which, in time, lead to the adoption of abnormal postures which affect the abilities of the CP patients' hands. The aim of this study was to identify the way the motor deficit at upper limb level - reflected by coordination disturbances and by the condition of the three-fingered (tripod) grasp - influences the CP patient's functional independence. The study demonstrated the existence of significant correlations between Functional Independence Measure (FIM) score ${ }^{2}$, coordination and three-fingered grasp. It was proven that the unilateral coordination dysfunctions have a strong negative influence on the coordination of the opposite side and lead to a decrease of the functional independence level. Therefore, the rehabilitation treatment is recommended to be based on a bilateral training, both in order to improve coordination and to obtain a functional level of the threefingered grasp power and of the physiological amplitude at wrist flexion level.
\end{abstract}

Keywords: cerebral palsy, functional independence, coordination, three-fingered grasp, wrist flexion.

\section{Rezumat}

Paraliziile cerebrale (PC) perturbă controlul voluntar al mișcării la nivelul extremităților, ducând la grade diferite de dizabilitate. În peste $80 \%$ dintre cazurile de PC există o afectare a membrului superior, manifestată predominant prin scăderea controlului la nivelul mâinii și prezența contracturilor ${ }^{1}$, acestea din urmă ducând în timp la adoptarea unor posturi vicioase care afectează abilitățile manuale ale pacienților cu PC. Scopul acestui studiu a fost acela de a identifica modul în care deficitul motor prezent la nivelul membrului superior - reflectat în tulburări de coordonare și afectarea pensei tridigitale - influențează independența funcțională a pacientului cu PC. Studiul a demonstrat existența unor corelații semnificative între scorul Functional Independence Measure (FIM)², coordonare și pensa tridigitală. S-a demonstrat că tulburările de coordonare unilaterale au o influență negativă puternică asupra coordonării de partea opusă și duc la scăderea nivelului de independență funcțională. Prin urmare, este recomandat ca tratamentul recuperator să fie bazat pe antrenament bilateral, atât pentru îmbunătățirea coordonării, cât și pentru obținerea unui nivel funcțional al forței pensei tridigitale și amplitudinii fiziologice la nivelul flexiei pumnului.

Cuvinte cheie: paralizie cerebrală, independență funcțională, coordonare, pensă tridigitală, flexia pumnului.

\section{INTRODUCTION}

The cerebral palsies (CPs) consist in permanent disturbances in the development of movement and posture, occurred further to a non-progressive lesion of the central nervous system during its development. It affects

${ }^{1}$ "Carol Davila" University of Medicine and Pharmacy, Bucharest, Romania

2 "Dr. Nicolae Robanescu" National Clinical Center for Children Neurorehabilitation, Bucharest, Romania (CNCRNC) the neuromuscular, musculoskeletal and sensorial systems entailing movement and posture deficiencies. The motor deficits entailed by anomalies of the muscular tonus and sensorial deficiencies manifest as abnormal movement patterns, asymmetric muscular contractions and deformations, all leading to disturbances of the ac-

\section{Corresponding author:}

Corina SPOREA, „Dr. Nicolae Robanescu” National Clinical Center for Children Neurorehabilitation, Bucharest, Romania.

E-mail: corina.sporea@gmail.com 
tivity with marks on the functional independence of the patient suffering from $\mathrm{CP}$.

\section{MATERIALS AND METHODS}

The study was performed during the years 2017-2020, within CNCRNC on a sample consisting in 45 patients aged between 6 and 9 year old, diagnosed with spastic $\mathrm{CP}$, having an intelligence coefficient of IQ $\geq 55^{3}$ and no significantly modified vision from the standard optotypic, compatible with the rehabilitation treatment within the study.

The study analyzed the influence of hand coordination disturbances and of the three-fingered grasp on the functional independence of the $\mathrm{CP}$ patient.

The study excluded the patients with severe psychical or neurological conditions, the ones with unstable or improperly consolidated fractures, osteoporosis, sensorial disturbances which might impede the reporting of any potential pain, spasticity MAS $\geq 3$ assesses on the Modified Ashworth Scale ${ }^{4,5}$, acute pains which failed to ease further to a conventional pain treatment, articular conditions of the upper limb which, by repeated mobilizations during training, could entail pains and irritations of the affected articulations and the ones whose attendants did not sign the informed consent.

The study was endorsed in advance by Etic Committee of CNCRNC No. 9586/15.12.2017. The patients were assessed upon admission. The clinical-functional assessment was performed using MAS and FIM Scales and the cinematic parameters were quantified using computer equipment, as follows: the coordination, i.e. the performance of a movement using a pre-established pattern, with the Myro system for the rehabilitation of the upper limb with neurological disorder, and the grasps with the Pablo system for the assessment and training of the arm and hand.

The statistical data processing was performed using the Statistical Package for the Social Sciences IBM SPSS Statistics 24 and Excel 2016 software.

The data processing for the analysis of the potential correlations between the collected data followed-up two statistical indicators: statistical significance $(p)$ and Pearson correlation coefficient (r) ${ }^{6,7}$.

\section{RESULTS AND DISCUSSIONS}

The survey group included female $56 \%$ and male subjects $44 \%$, from both urban and rural areas. In relation to the type of spastic $\mathrm{CP}$, the most frequent form within the study group was the tetraplegic one (PCSQ) 38\%, followed by the hemiplegic (PCSH) $36 \%$, diplegic (PCSD) 24\% and dyskinetic (PCSK) $2 \%$ (Table 1). In terms of sensorial disorders, within the analyzed sample, we identified: vision $51 \%$, acoustic $7 \%$, speech $38 \%$, sleep $24 \%$, concentration $62 \%$ and coordination $91 \%$ disorders.

At the upper limb level, the most frequent form was the unilateral right disorder (47\%), followed by the unilateral left $33 \%$ and bilateral ones, relatively symmetrical 20\%.

By analyzing the functional independence score (FIM) in relation to the $\mathrm{CP}$ type we note that the higher independence degree is registered by the PCSH patients, these having a median value and a measure of the central tendency equal to 98.5 (Figure 1).

Table 1. FIM distribution based on the cerebral palsy type

\begin{tabular}{|c|c|c|c|c|c|c|c|c|}
\hline \multicolumn{9}{|c|}{ FIM } \\
\hline Type & $\mathrm{N}$ & Mean & Median & $\begin{array}{l}\text { Grouped } \\
\text { Median }\end{array}$ & $\begin{array}{l}\text { Std. Error } \\
\text { of Mean }\end{array}$ & Minimum & Maximum & Variance \\
\hline PCSH & 16 & 86.56 & 98.50 & 98.50 & 9.678 & 19 & 126 & 1498.529 \\
\hline PCSD & 11 & 81.64 & 80.00 & 80.00 & 8.790 & 32 & 126 & 849.855 \\
\hline PCSQ & 17 & 91.12 & 91.00 & 91.00 & 7.483 & 45 & 126 & 951.985 \\
\hline PCSK & 1 & 61.00 & 61.00 & 61.00 & . & 61 & 61 & . \\
\hline Total & 45 & 86.51 & 91.00 & 90.67 & 4.897 & 19 & 126 & 1079.119 \\
\hline
\end{tabular}




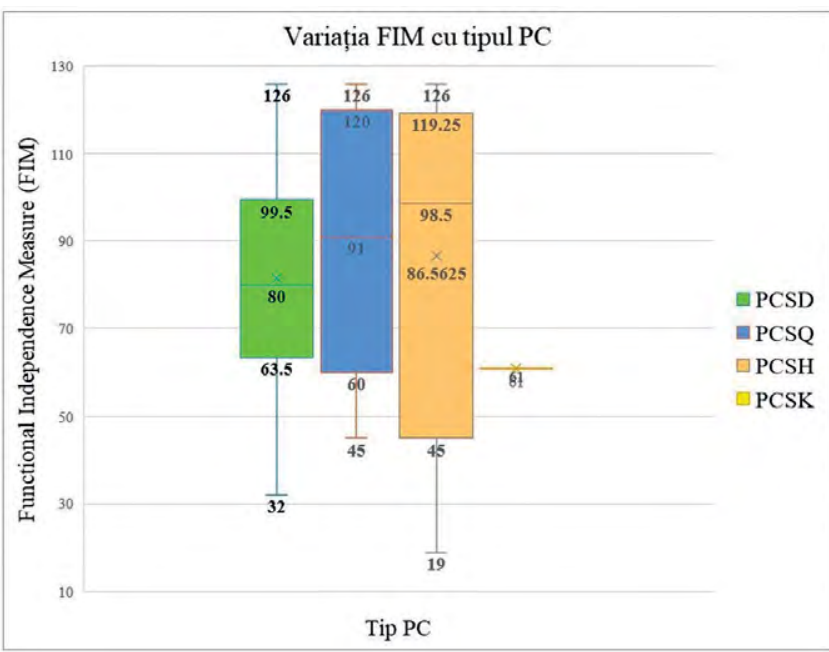

Figure 1. FIM score variation with the cerebral palsy type

The effect of the motor deficit localization on the FIM score was analyzed using the ANOVA one-way analysis of variance, the Bonferroni test, the research hypothesis: the affected area influences the FIM values and the null hypothesis: FIM has the same value irrespective of the affected area.

Table 2. Influence of the motor deficit localization on the FIM Score ANOVA

\begin{tabular}{|c|c|c|c|c|c|}
\hline \multicolumn{7}{|c|}{ ANOVA FIM } \\
\hline & Sum of Squares & df & Mean Square & F & Sig. \\
\hline Between Groups & 9861.022 & 2 & 4930.511 & 5.505 & .008 \\
\hline Within Groups & 37620.222 & 42 & 895.720 & & \\
\hline Total & 47481.244 & 44 & & & \\
\hline
\end{tabular}

The intergroup freedom for which the threshold $\mathrm{F}=5.505$ value was calculated is 2 , and intragroup one is 44 (Table 2). The test is significantly statistical, $\mathrm{p}=0.008$, therefore the null hypothesis is rejected, the conclusion being that motor deficit localization influences the FIM score.

By analyzing the influence of the motor deficit localization (left hand, right hand and both) on the FIM score, we noted that the strongest influence is exercised by the deficit localized in the right hand, followed by the left localization and by the localization in both hands (Table 3 ). The analysis did not take into account the severity, but only the localization of the deficit, so we do not exclude the probability that the results could register modifications depending on the illness severity. The study analyzed the potential correlations between the FIM score, the upper limb coordination on the healthy side (coord_s_T) and the affected one (coord_ bv_T), the three-fingered grasp on both side - healthy (grasp3dgt_s) and affected (grasp3dgt_bv) - and the wrist flexion at the healthy limb (F_wrist_s) and at the affected limb (F_wrist_bv) level.

Table 3. Influence of the motor deficit localization on the FIM - differences between groups

\begin{tabular}{|c|c|c|c|c|c|c|}
\hline \multicolumn{7}{|c|}{ Multiple Comparisons } \\
\hline \multicolumn{7}{|c|}{ Dependent Variable: FIM } \\
\hline \multicolumn{7}{|c|}{ Bonferroni } \\
\hline \multirow{2}{*}{ (I) affected side } & \multirow{2}{*}{$(\mathrm{J})$ affected side } & \multirow{2}{*}{$\begin{array}{c}\text { Mean Difference } \\
(\mathrm{I}-\mathrm{J})\end{array}$} & \multirow{2}{*}{$\begin{array}{l}\text { Std. } \\
\text { Error }\end{array}$} & \multirow{2}{*}{ Sig. } & \multicolumn{2}{|c|}{ 95\% Confidence Interval } \\
\hline & & & & & Lower Bound & Upper Bound \\
\hline \multirow{2}{*}{ Right } & Left & 7.000 & 10.118 & 1.000 & -18.23 & 32.23 \\
\hline & Both & $39.111^{*}$ & 11.924 & .006 & 9.38 & 68.85 \\
\hline \multirow{2}{*}{ Left } & Right & -7.000 & 10.118 & 1.000 & -32.23 & 18.23 \\
\hline & Both & $32.111^{*}$ & 12.619 & .044 & .64 & 63.58 \\
\hline \multirow{2}{*}{ Both } & Right & $-39.111^{*}$ & 11.924 & .006 & -68.85 & -9.38 \\
\hline & Left & $-32.111^{*}$ & 12.619 & .044 & -63.58 & -.64 \\
\hline
\end{tabular}


Table 4. Analysis of the Correlations between the FIM Score, coordination of the upper limb, the three fingered grasp and wrist flexion

\begin{tabular}{|c|c|c|c|c|c|c|c|c|}
\hline \multicolumn{9}{|c|}{ Correlations } \\
\hline & & FIM & $\begin{array}{l}\text { coor- } \\
\text { d_s_T }\end{array}$ & $\begin{array}{c}\text { coord_ } \\
\text { bv_T }\end{array}$ & $\begin{array}{l}\text { grasp } \\
\text { 3dgt_s }\end{array}$ & $\begin{array}{c}\text { grasp } \\
\text { 3dgt_bv }\end{array}$ & $\underset{\text { wrist_s }}{\mathrm{F}_{-}}$ & $\underset{\text { bv }}{\text { F_wrist_ }}$ \\
\hline \multirow{3}{*}{ FIM } & Pearson Correlation & 1 & $-.722^{\text {** }}$ & $-.740^{* *}$ & $.423^{* *}$ & $.334^{*}$ & .106 & .078 \\
\hline & Sig. (2-tailed) & & .000 & .000 & .004 & .025 & .490 & .609 \\
\hline & $\mathrm{N}$ & 45 & 45 & 45 & 45 & 45 & 45 & 45 \\
\hline \multirow{3}{*}{ coord_s_T } & Pearson Correlation & $-.722^{* *}$ & 1 & $.893^{* *}$ & $-.422^{* *}$ & -.242 & -.111 & -.050 \\
\hline & Sig. (2-tailed) & .000 & & .000 & .004 & .109 & .466 & .745 \\
\hline & $\mathrm{N}$ & 45 & 45 & 45 & 45 & 45 & 45 & 45 \\
\hline \multirow{3}{*}{ coord_bv_T } & Pearson Correlation & $-.740^{* * *}$ & $.893^{* *}$ & 1 & -.274 & -.204 & -.050 & -.013 \\
\hline & Sig. (2-tailed) & .000 & .000 & & .069 & .179 & .745 & .932 \\
\hline & $\mathrm{N}$ & 45 & 45 & 45 & 45 & 45 & 45 & 45 \\
\hline \multirow{3}{*}{ grasp3dgt_s } & Pearson Correlation & $.423^{* *}$ & $-.422^{* *}$ & -.274 & 1 & $.548^{* *}$ & .076 & .291 \\
\hline & Sig. (2-tailed) & .004 & .004 & .069 & & .000 & .621 & .053 \\
\hline & $\mathrm{N}$ & 45 & 45 & 45 & 45 & 45 & 45 & 45 \\
\hline \multirow{3}{*}{ grasp3dgt_bv } & Pearson Correlation & $.334^{*}$ & -.242 & -.204 & $.548^{* *}$ & 1 & -.197 & $.334^{*}$ \\
\hline & Sig. (2-tailed) & .025 & .109 & .179 & .000 & & .195 & .025 \\
\hline & $\mathrm{N}$ & 45 & 45 & 45 & 45 & 45 & 45 & 45 \\
\hline \multirow{3}{*}{ F_wrist_s } & Pearson Correlation & .106 & -.111 & -.050 & .076 & -.197 & 1 & $.345^{*}$ \\
\hline & Sig. (2-tailed) & .490 & .466 & .745 & .621 & .195 & & .020 \\
\hline & $\mathrm{N}$ & 45 & 45 & 45 & 45 & 45 & 45 & 45 \\
\hline \multirow{3}{*}{ F_wrist_bv } & Pearson Correlation & .078 & -.050 & -.013 & .291 & $.334^{*}$ & $.345^{*}$ & 1 \\
\hline & Sig. (2-tailed) & .609 & .745 & .932 & .053 & .025 & .020 & \\
\hline & $\mathrm{N}$ & 45 & 45 & 45 & 45 & 45 & 45 & 45 \\
\hline \multicolumn{9}{|c|}{ **. Correlation is significant at the 0.01 level (2-tailed). } \\
\hline
\end{tabular}


Three significant strong correlations were registered ( $\mathrm{p}$ $<0.001$ ), between the FIM score and the healthy side coordination $(r=0.722)$, FIM score and the affected side coordination $(r=0.740)$ and between the coordination of the two hands $(r=0.893)$. Three moderate correlations were found between the FIM score and the three fingered grasp at the healthy hand $(r=0.423)$, between the coordination and the three-fingered grasp at the heathy hand $(\mathrm{r}=0.422)$ and between the three-fingered grasps at both hands' level $(r=0.548)$.

A comparative analysis envisaged paired samples at the two upper limbs' level: the healthy hand (S) vs. the affected hand $(\mathrm{Bv})$ based on the parameters below:

- Time (CST - CSBvT ) - coordination expressed in seconds, i.e. the time taken by the patient to accurately complete a task - the lower the value of the parameter, the better the result;

- Accuracy (CSP - CSBvP) - coordination expressed in percentages, i.e. the percentage to which the $\mathrm{pa}^{-}$ tient managed to follow a trajectory - the greater the value of the parameter, the better the result;

- Wrist flexion FPS - FPBv;

- Three-fingered grasp P3dgtS - P3dgtBv.
The aspects below were highlighted (Table 5):

1. The average value of the CST $=39.31$, smaller than $\mathrm{CBvT}=56.78$, showed that the patient completed the task faster using the healthy hand; we noted a strong correlation of the two variables $(r=0.893)$, the test being highly significant $(\mathrm{p}<0.001)$.

2. In terms of accuracy, this was better at healthy hand level, CSP > CSBvP, the variables being strongly and significantly correlated $(\mathrm{r}=0.751, \mathrm{p}<0.001)$.

3. The wrist flexion, greater at the healthy hand, is not correlated with the opposite side; the testing of the variables' differences indicated an approx. $25^{\circ}$ higher amplitude of movement with the healthy limb.

4. The three-fingered grasp was stronger on the healthy side, and the two paired variables were strongly and significantly correlated $(r=0.548, p<0.001)$.

\section{CONCLUSIONS}

The unilateral coordination disorders have a strong negative influence on the coordination of the opposite side and entail the decrease of the functional independence level. The motor deficit localized in the right upper limb, compared to the left limb, produces a greater alteration of the functional independence.

Table 5. Analysis of the paired samples

\begin{tabular}{|c|c|c|c|c|c|c|}
\hline \multicolumn{4}{|c|}{ Paired Samples Statistics } & \multicolumn{3}{|c|}{ Paired Samples Correlations } \\
\hline & & Mean & $\mathrm{N}$ & Pair & Correlation & Sig. \\
\hline \multirow{2}{*}{ Pair 1} & CST & 39.31 & 45 & \multirow{2}{*}{$\mathrm{CST} \& \mathrm{CBvT}$} & \multirow{2}{*}{.893} & \multirow{2}{*}{.000} \\
\hline & CBvT & 56.78 & 45 & & & \\
\hline \multirow{2}{*}{ Pair 2} & CSP & 0.8722 & 45 & \multirow{2}{*}{ CSP \& CBvP } & \multirow{2}{*}{.751} & \multirow{2}{*}{.000} \\
\hline & $\mathrm{CBvP}$ & 0.7176 & 45 & & & \\
\hline \multirow{2}{*}{ Pair 3} & FPS & 67.3911 & 45 & \multirow{2}{*}{ FPS \& FPBv } & \multirow{2}{*}{.345} & \multirow{2}{*}{.020} \\
\hline & $\mathrm{FPBv}$ & 42.1489 & 45 & & & \\
\hline \multirow{2}{*}{ Pair 4} & P3dgtS & 3.4689 & 45 & \multirow{2}{*}{$\begin{array}{l}\text { P3dgtS \& } \\
\text { P3dgtBv }\end{array}$} & \multirow{2}{*}{.548} & \multirow{2}{*}{.000} \\
\hline & P3dgtBv & 2,1289 & 45 & & & \\
\hline
\end{tabular}


The unilateral diminution of the three-fingered grasp force has a moderate influence on the affected side's wrist flexion and also produces a decrease of the functional independence level.

Based on the information above we can strongly confirm that the recommended rehabilitation treatment should be based on the bilateral training, both for the coordination improvement, and for the obtaining of functional level of the three-fingered grasp force and of the wrist flexion physiological amplitude.

\section{ACKNOWLEDGEMENTS}

This study is part of the research carried out within the doctoral thesis bearing the title „Researches on Integrated Modes for the Development of Digital and Preparatory Abilities for Writing, for Children with Cerebral Palsy".

\section{References}

1. Makki D, Duodu J, Nixon M. Prevalence and pattern of upper limb involvement in cerebral palsy. J Child Orthop. 2014;8(3):215-9.

2. Functional Independence Measure [Internet]. Available from: https://www.strokengine.ca/en/indepth/fim_indepth/

3. Mash E, Wolfe D. Intellectual Disability and Developmental Disorders. In: Abnormal Child Psychologysychology. 7th ed. Boston: Cengage Learning; 2019. p. 672.

4. Charalambous CP. Interrater reliability of a modified ashworth scale of muscle spasticity. Class Pap Orthop. 2014;415-7.
Compliance with ethics requirements: The authors declare no conflict of interest regarding this article. The authors declare that all the procedures and experiments of this study respect the ethical standards in the Helsinki Declaration of 1975, as revised in 2008(5), as well as the national law. Informed consent was obtained from all the patients included in the study.

5. Modified Ashworth Scale [Internet]. Available from: https://www strokengine.ca/en/indepth/mashs_indepth/

6. StatisticsSolutions. Pearson's Correlation Coefficient [Internet] [cited 2020 Sep 30]. Available from: https://www.statisticssolutions.com/pearsons-correlation-coefficient/

7. Williams F, Monge P. Reasoning with statistics: How to read quantitative research. 5th Editio. Orlando, Florida, USA: Harcourt College Publishers; 2001. 228 p. 